\title{
LANGUAGE APPRAISAL ON ATTITUDINAL SYSTEMS FOR EXPLORING IDEOLOGY IN DEATH PENALTY IN SYDNEY MORNING HERALD AND HERALD SUN EDITORIALS
}

\author{
Rosyida Ekawati*
}

\begin{abstract}
ABSTRAK
Artikel ini membahas ideologi yang direpresentasikan oleh editorial surat kabar. Hal ini berawal dari pemahaman bahwa penggunaan bahasa tidak pernah netral dan tidak bebas ideologi. Bahasa yang digunakan untuk menyampaikan makna dalam arti luas. Ada makna yang berkaitan dengan pendapat melalui bahasa sebagai sumber evaluasi. Editorial adalah salah satu praktek bahasa yang penuh dengan opini terhadap permasalahan terkini atau isu tertentu. Artikel ini menggunakan editorial dari Sydney Morning Herald dan Herald Sun yang merupakan surat kabar Australia. Kedua surat kabar tersebut menduduki peringkat tinggi dalam hal sirkulasi dan akses secara online. Artikel ini mengungkap ideologi yang diwakili oleh kedua editorial surat kabar mengenai hukuman mati grup Bali sembilan yang dilaksanakan di Indonesia. Melalui perspektif sikap yang dikemukakan oleh Martin dan White (2005) dalam hal mempengaruhi, penilaian, dan penghargaan dalam perpektif penilaian bahasa digunakan untuk mengeksplorasi ideologi dalam surat kabar tersebut. Dari analisis penilaian, ditemukan bahwa Indonesia secara dominan dinilai dalam penilaian negatif sementara Australia digambarkan dalam pandangan positif untuk masalah hukuman mati di Indonesia. Tidak ada apresiasi positif bagi Indonesia dalam editorial surat kabar tersebut.
\end{abstract}

Kata kunci: editorial, mempengaruhi, penghargaan, penilaian, penilaian bahasa

\begin{abstract}
This article deals with the ideology represented by newspaper editorials. It is from the idea that every language use is never neutral and not ideology-free. Language is used to convey meanings in a broad sense. There are meanings related to the opinions through the language as resources of evaluation. Editorial is one practice of language use full of opinions towards a certain issue on people or things. Sydney Morning Herald and Herald Sun are used as both Australian newspaper posit themselves as the high-rank newspaper in terms of circulation and online accessed. This article tries to uncover the ideologies represented by both newspaper editorials concerning death penalty of Bali Nine executed in Indonesia. Attitudinal perspective proposed by Martin and White (2005) in term of affect, judgement, and appreciation of language appraisal is used to explore ideology in the newspaper. From appraisal analysis, it is found that Indonesia dominantly appraised in negative
\end{abstract}

\footnotetext{
* English Study Program, Faculty of Social and Cultural Sciences University of Trunojoyo Madura
} 
judgement while Australia is portrayed in positive view for the issue of death penalty in Indonesia. There is no positive appreciation for Indonesia in both newspaper editorials.

Keywords: affect, appreciation, editorial, judgement, language appraisal

\section{INTRODUCTION}

Media is one of the effective and efficient channels of disseminating information. Printed and online media nowadays provide information or ideas for society from various perspectives. So, media can contribute significantly to shaping our worldviews towards other societies and cultures. In expressing opinion on people, things, and situations, of course, the writer or journalist uses a certain language. As a language is never neutral and not ideology-free, language can be a power to dominate others. It is the language that is used to convey a broad sense of meaning through the social, political, and historical conditions. Then, there are meanings related to the opinions through the language as resources of evaluation or appraisal in language.

Appraisal framework is a particular approach to exploring, describing, and explaining the way language is used to evaluate, adopt stance, construct interpersonal positions and relationships. From three kinds of appraisal resources proposed by Martin and White (2005), attitude plays an important role in the expression of interpersonal meanings of language. It refers to a way that we behave towards someone or in a particular situation, especially when this shows how we feel. This article deals with the expression of interpersonal meaning in the area of media discourse, particularly focusing on newspaper editorials discourse.

Media are usually understood to refer to the broadcasting agency of the press, radio, and television that have become true media for dissemination of information in a globalized world. Newspapers, which is the main product of the print media, have a variety of consumer and distributed to a wide audience with different aspects and become a point of attraction to the reader. These parts of newspaper include the feature pages, page column, front page, sports, and editorial columns.

In details, editorial is a column written by the editor expressing his opinion on a particular topic of interest (Imhonopi and Urim, 2004: 189).
This is because it shows the three main issues (1) indent editorial written by the editor; (2) it is an expression of the editor's opinion representing media organizations; and, (3) it is about a specific topic of interest that can be a focus of local or international society. So, the editorial page is a commentary on the key issues and sensitive has been previously discussed in the report. The purpose of the editorial is primarily to express and construct public opinions (van Dijk, 1996)

Medubi (2007: 116) provides certain features of the editorial and the language and editorial style. Among the features are: a) it must be simple so that it is easy to understand; b) it should also have aesthetic appeal; c) it should adopt the high notes, for example printed in bold type and use a wider column; d) it provides enlightenment on issues; e) it indicates completeness in the sense of presenting the issues studied; $f$ ) it is represented on the position of knowledge. There is an emphasis on editorial core functions that they serve the interests of society in terms of socio-political and economic. As a wrap up, the views of the editorial as Storall (2005:7) view is important because many journalists consider that the news, business, sports and features as a function of the newspaper, then the editorial page, however, is the soul of the newspaper.

Foremost, this article evaluates the strategies used by newspaper editors in expressing an idea of a certain issue or topic. This system of evaluation, Martin and White's (2005) Appraisal Framework, forms the basis of the interpretation of the data by adding amendments, offering a more robust conceptualisation where interpersonal meaning in media discourse can be seen. As well as providing an interpretation of evaluative meaning, this article provides a comparison between two Australian newspaper editorials on death penalty of Bali Nine in Indonesia. It will be analysed from their meaning patterns compared both within and across each newspaper. This allows us to determine the strategies employed within each newspaper as well as the kind of community of 
feeling constructed by them through the media and editorials discourse that they employ.

The death penalty execution for Bali Nine has provoked the Australians and so far influenced the relationship between Indonesia and Australia. Australia is in the position of opposing such kind of capital punishment. Various ways of Australians expressing their feeling on the policy of death penalty through some protests toward Indonesia have emerged. From that, it is worth to analyze the language used by the Australian newspaper editorials in presenting the attitudinal systems towards the death penalty execution in Indonesia for exploring ideology in the newspaper. For more spesific, the objectives of the study are to analyze the ideology of the media and the linguistic strategy used in representing their ideology.

\section{THEORETICAL REVIEW}

One of the ways to understand ideology from linguistic point of view is through Systemic Functional Linguistics (SFL). It is a theory of language which highlights the relationship between language, text and context (Halliday \& Hasan, 1989). It is also a functional theory of language which describes how people use language to make meanings in context (Halliday \& Matthiessen, 2004). In this sense, systemic means meaning making or sense making in context and functional means a description of language functions.

Coffin (2001) also theorizes that Systemic Functional Lingusitics (SFL) is primarily a linguistic theory that concerns with the effect of culture and society of language. The theory argues that all of the speakers are affected by socio-economic systems in which they live and also the role they occupy in the system. Fowler (1986: 148) provides examples such as birth, family, school and social groups affiliated, together with patterns of interactions and limitations related experiences with them as the evidences of the claim. Thus each speaker creates language action, making linguistic choices bounded by semantic repertoire provided by their personal and cultural or social experiences. A text, then, provides the reader with a view of the world as seen or understood by the writer or speaker.

Within Halliday's SFL perspective, language as a social phenomenon is functional (Haratyan, 2011). In general, SFL takes a functional orientation which means that a focus on what language does is more important than looking at its structure. So, it concerns with the mechanism of text structure, function and meaning of language. It begins an analysis of language in social context where a particular lexico-grammatical choice is constructed under the influence of the social and cultural context. In SFL, meaning is achieved through the linguistic choices where the words are arranged in a clause or text.

In SFL, the ways in which human beings use language are classified into three categories known as metafunctions (Bloor and Bloor, 2004: 10-11). They are ideational, interpersonal, and textual metafunctions. The ideational metafunction is classified into two subfunctions: the experiential and the logical. In this category, language is used to organize, understand and express our perceptions of the world and of our own consciousness. The experiential is largely concerned with content or ideas. The logical is concerned with the relationship between ideas. Within interpersonal metafunctions, language is used to enable us to participate in communicative acts with other people, to take on roles and to express and understand feelings, attitude and judgements. Then, when language is used to relate what is said (or written) to the rest of the text and to other linguistic events, and to relate the use of language to organize the text itself is known as the textual metafunction. Each function has its own developmental framework as a tool for a deeper understanding of language.

According to Halliday (2000), the interpersonal metafunction concerns how the language to realize the dynamic meaning of the language to show the relationship between the speaker and the hearer, and how to use language to express one's attitude and to influence the hearers. This metafunction attempts to explore the ways in which language is used for the evaluation of the attitude of the discourse producers. It provides techniques for systematic analysis and evaluation of the speaker's or wtiter's attitude operates throughout the text. Then, it deals with the social function of these resources, not only as a means of discourse of individual producers to express their feelings but as the means by which they are involved with social value-determined position and adjust to social subjects of their position. 
In addition, the interpersonal meaning helps to establish and maintain social relations. The individual is identified and reinforced in this aspect by enabling him/her to interact with others by expression of their own individuality. Our role relationships with other people and our attitudes towards others are often expressed by interpersonal meaning. This line of meaning in a clause comes from the clause serving as an exchange (Halliday, 1994:66; Halliday and Matthiessen, 2004: 105).

The interpersonal metafunction refers to the state in which the speaker uses language as the means of his own intrusion into the speech event (Halliday, 1971: 333). Here, it includes the expression of his own comments, attitudes and evaluations (Clark 2007: 151), and also the relationship that he sets up between himself and the listener in particular, the communication role that he/she adopts of informing, questioning, greeting, persuading, and the like. A framework that has been developed by Martin and White (2005) to investigate and analyze language function, in particular for interpersonal meanings, is language appraisal framework.

Appraisal framework, which was put forward by James Martin at the beginning of the 1990s, is an extension of Halliday's Systemic Functional Linguistics. It serves as an analytical tool to get a better understanding of some issues which associated with evaluative resources and the negotiation of intersubjective positions,opening a new area of interpersonal meaning (Liu, 2010). It is one of three major discourse semantic resources construing interpersonal meaning (Martin \& White, 2005: 34).

Language appraisal is categorized into three domains, namely attitude, engagement, and graduation. Attitude is concerned with our feelings, including emotional reactions, judgements of behavious and evaluation of things. Engagement deals with sourcing attitudes and the play of voices around opinions in discourse. Graduation attends to grading phenomena whereby feelings are amplified and categories blurred.

Attitude, which refers to the positive or negative assessment of a person, place, thing, or matter, involves three semantics sphere in interpreting emotions, ethics, or aesthetics (Martin
$\&$ White, 2005). For example, I can claim that I am very happy with the article, that the writer is skillful, or that of piece of writing is strong. The difference is in what is assessed - the reaction of my own to write, the behavior of the author, or the writing itself.

Figure 1.

An Overview of Appraisal Resources (Martin \& White, 2005: 38)

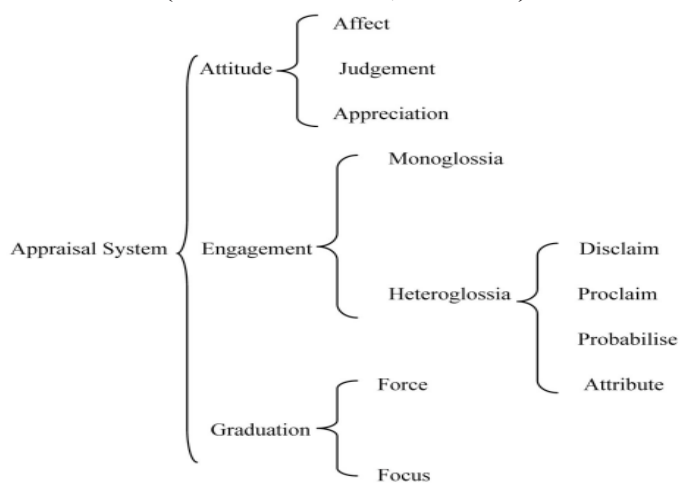

Affect concerns with resources to interpret emotional reactions, for example the feeling of shock in relation to a particular event. This relates to express positive and negative feelings, such as happy or sad, confident or anxious, interested or bored. Martin and White (2005: 46) classify affect into affect as quality, affect as a process, and affect as a comment. Affect as quality deals with the description of the participants (teachers happy), attribution of participants (teachers happy), and manner of process (teacher left happily). Affects as process deals with mental processes (he missed) and affective behavior (child crying). Meanwhile, affect as comment refers to desiderative (happily, they had to go).

Judgement relates to resources to assess the behaviour according to various normative principles. It deals with the attitude toward the behaviour, which we admire or criticize, praise, or condemn. Classification of judgment is social esteem consisting of normality, capacity, and tenacity and social sanctions consisting of veracity and propriety.

Appreciation involves the evaluation of semiotic and natural phenomena, according to the ways in which they are valued or not in a particular field. It can be divided into reaction, composition, and valuation. Reaction is related to affection; composition is related to perception; and valuation is related to cognition. 


\section{METHODOLOGY}

This study is descriptive qualitative to deal with the complexities of meanings in social contexts. Qualitative research concerns with the collection, analysis and interpretation of data in order to gain insights into a particular phenomenon of interest (Gay et al., 2006). Because the primary goal of qualitative research is understanding, the researcher is the primary instrument for data collection and analysis. Source of the data is Australian newspaper editorials, Herald Sun (HS) entitled Death stalks the Bali Two and Sydney Morning Herald (SMH) entitled Mankind diminished by barbarism in the cause of political expediancy. They are from different group owners but on the high rank position for both circulation and online accessed. The data are in forms of words or phrases of the editorials. The analysis starts by reading the editorials, from the first part to the last one, to facilitate recall of the highlight contents. It is text-based analysis that means the analysis is per text. Finishing each text, then make some kind of generalization from the editorials. The table is used to display the data of appraisal items, appraiser, categorization of the attitudinal systems, and appraised item. As the focus of the study is interpersonal metafunctions of the language used in newspaper editorials, interpretation and discussion are based on the theory of Systemic Functional Linguistics especially on the level of discourse semantic of appraisal on attitudinal perspective lead to the understanding of ideology of the newspaper.

\section{DISCUSSION}

The system of attitude is presented in this section focusing on the two editorial texts of SMH and HS. It starts from the bottom-up, beginning with words or appraisal items and appraised items of each editorial. It is explained the attitudinal systems leading to the ideology on SMH and HS editorials. From the genre of editorials, often the editors of the newspaper share their emotions, pass judgment and give valuation about relevant people, things and states of affairs as well. Therefore, attitude is a prominent point to realize the interpersonal meanings which comprises affect, judgment and appreciation.
Text 1. SMH editorial: Mankind diminished by barbarism in the cause of political expediancy

\section{Affect Analysis}

SMH entitled its editorial Mankind diminished by barbarism in the cause of political expediancy which refers to the death penalty execution of the two Australian on 29 April 2015 who convicted for smuggling $8.3 \mathrm{~kg}$ of heroin valued at around 3.1 million US dollars from Indonesia to Australia.

Affect analysis within the SMH editorial mostly describes the emotional feeling of the Australian toward the death penalty of 'members' of Bali Nine, Andrew Chan and Myuran Sukumaran. Embodied in negative affects of their feelings, such as fear, doubt, and angry. There are no positive affects representated in the SMH editorial for both Indonesia and Australia.

Knowing the death penalty execution of two Australians, Chan and Sukumaran, Australians in general have the same feeling as them. They are in the worst fears as the execution is considered to be one of the evil things they have faced along their lives. None they feel such the inscribed feeling before.

(1) Australians awoke on Wednesday to their worst fears, to realise the evil that men do still extends to the apparatus of state. (SMH)

It indicates that they are not happy with the evil deeds. From the co-text of the word 'awoke', it means they just realized what happened to the two Australians is fully frightening because of the evil of the apparatus of state. The apparatus of state refers to Indonesian government that penalize the two Australians the death sentence. Further, the Australians also feel unsatisfied on the capital punishment to Chan and Sukumaran. They are angry on the decision of executing them. They ask for retribution, although they realize that it is not easy to do it.

(2) The Herald understands that many angry Australians will want retribution, but blaming the Indonesian people will not achieve anything. (SMH) 
Instead of the Australians feelings on the execution, the defendants also have the negative affect for unhappiness on what they will face in their near future life. They replete with doubt on the death sentence they got. They feel hesitant on the process that has already been undertaken. It is fair if the process of clemency appeals and process of execution are what make them feeling doubtful. The appeals by Andrew Chan and Myuran Sukumaran are rejected by the Bali high court and many times for clemency appeals are rejected by the Indonesian presidents.

(3) The process by which these sons, brothers and mates were sentenced to death remains replete with doubt. (SMH)

The death execution done to Chan and Sukumaran and for this matter, Australia cannot avoid it. Then, the only desire toward every nation that commits on capital punishment, SMH suggests the Australian government to holding each other and with other global institutions to end such kind of executions.

\section{Judgement Analysis}

Judgement analysis deals with social esteem and sosial sanction, both with positive and negative perspectives. In this matter, it is kind of judging people's character both positive and negative and they may be judged explicitly or implicitly (Martin and White, 2005). Judging people's characters can be divided into personal (e.g. admiring, criticizing) and moral judgment (e.g. praise, condemnation). The judgement appraisal goes to Mr. Joko Widodo, Indonesian government, Indonesia as a nation, Australians, Andrew Chan and Myuran Sukumaran, death punishment, Tony Abbott and SMH itself.

\section{a. The judgement system of capacity}

These are resources we utilize to evaluate someone's skill, strength, and/or aptitude for carrying out certain social tasks. Negative judgement of capacity toward Joko Widodo as the president of Indonesia is inscribed in the editorial.

(4) The Indonesian President has shown himself incapable of the most basic human responses: mercy and compassion. (SMH)
Through a certain extent of the process of presidency, he shows that he is not capable in rendering human need. SMH evaluates that he has no capacity to fulfill the basic need of humanity. It is valued that as the president, he is obliged to be merciful to human. Within the editorial column, the statement is delivered twice. It can be to emphasizing the real capability of the president.

Instead of the negative capacity of the president personally, Indonesian government and Indonesia as a nation is also appraised witihin social esteem to have negative capacity or incapable in sentencing the Australian defendant, Chan and Sukumaran. There is a gross error of the Indonesian government to make kind of judgement to them. Capital punishment is not fair as $\mathrm{SMH}$ states the two men have already done a lot of things as the compensation of their errors.

Furthermore, Indonesia is judged to have another negative capacity in reviving execution. The wrong decision is made by the Indonesian government for denying the clemency for the people who have changed for almost a decade. The words such as 'culpability' and 'simply wrong' are the evidences that SMH appraises Indonesia government incapable to provide justice for those who sentenced in court but already changed for the time being.

(5) Indonesia's culpability in reviving executions for convicted drug criminals and denying the Australian pair clemency is no better nor worse than the policies of China for killing political prisoners or indeed so many states in the US for killing murderers. (SMH)

(6) It is simply wrong. (SMH)

Aside from that, Chan and Sukumaran are also appraised in negative capacity. They are criticized as criminals, drug criminal. Although it is mentioned as criminals, in reverse, they need justice by sending the clemency to the president.

\section{b. The judgement system of tenacity}

Tenacity, another category of judgement that is attitudinal meanings we utilize to assess someone's determination to accomplish a particular piece of work. Tenacity also appears in the SMH editorial. There is only one tenacity expressed for evaluating the death execution. 
These were lives cut short and the potential for good extinguished for no reason. (SMH)

From that, it is understood that from SMH point of view it is unreasonable for the death execution.

\section{c. The judgement system of veracity}

In the editorial, there is only one judgement of social esteem category of veracity. It is concerned with evaluations for assessing behavior that pertains to the moral domains of sincerity and honesty. That is, judgements of veracity are assessments we use to express how truthful and honest we think someone is. So, judgement of veracity deals with the truth. By stating 'The justification for killing offenders in the name of deterrence has been exposed as a fraud', SMH judges Indonesia to be a liar because any killing offenders is not true with any reasons including for precaution.

\section{d. The judgement system of propriety}

It encompasses resources for evaluating behavior in terms of what is considered ethical or unethical by a particular community. In other words, values of propriety concern the social sphere of right-versus-wrong or good-versus-evil behavior, which most societies tend to punish with sanctions enforced by law. The judgement system of social sanction, propriety in this matter, is mostly negative in presenting the Indonesian president in specific or Indonesian government and nation in general.

Indonesia is cynically invoked as the evil, barbarism, cruel, inhumane, haphazard, and inconsistent. President Joko Widodo is regarded to be haphazard and inconsistent in conducting his duties.

(8) Australians awoke on Wednesday to their worst fears, to realise the evil that men do still extends to the apparatus of state. (SMH)

(9) Above all mankind has been diminished by yet another act of barbarism in the cause of political expediency. (SMH)

(10) The process by which Indonesia has pursued these executions has been cruel and inhumane. (SMH)

(11) The process by which Mr Joko has exercised his duties as a national leader has been haphazard and inconsistent. (SMH)
This assessment is offered as he pursues capital punishment for other citizens who have changed for long time. His inconsistency is showed when the Indonesian president also proposes an appeal for the Indonesian citizen who face death sentence in other countries. Meanwhile, the assessment of cruel and inhumane refers to the process of execution. The overall process and execution of capital punishement are called as the act of barbarism and evil.

In reverse, to assess the Australian Prime Minister, Tony Abbott, the journalist indicates him in positive judgement of propriety. All Abbot's efforts concerning the death execution of his citizen are right. He does not want to worsen any situation but keeping the communication with Indonesia. The purpose of Abbott' effort is to educate the Indonesian not to be inhuman, but what the Indonesians do must have values.

(12) But Prime Minister Tony Abbott is right: we do not want to make a bad situation worse. $(\mathrm{SMH})$

From that invoked judgement, clearly, the journalist intends to say that Indonesia is so far inhuman and everything they do is useless and unreasonable. Australia is claimed in positive way in which it is one step ahead comparing to Indonesia in term of humanity.

\section{Appreciation Analysis}

Appreciations are used for expressing positive and negative evaluations of texts, objects, entities, processes, or natural phenomena. Within this evaluation, Joko Widodo as the president of Indonesia also appraises in positive way of Indonesia, but editorial does not say so. Appreciations of the editorial deal with reaction, composition and valuation.

\section{a. Appreciation system of reaction}

Reaction is related to affection (emotive). In the editorial, the evaluation of positive reaction goes to Australian diplomacy. The journalist indicates that what Australia do regarding to the execution is not niceties. It is a serious case that needs a serious diplomacy. The Australian government wants to show the whole-hearted effort to struggle for its citizen, so the Australian government withdraws 
the Australian ambassador from Jakarta unless Indoensia fulfill any requirements proposed by Australia. Then, if Indonesia does so, Australia guarantees that the relationship between both countries will be more trusting and constructive on the future.

Joko Widodo, the president of Indonesia is appreciated to be fail in every efford he pursues as the president. It is stated 'On every count, Mr Joko and Indonesia have failed.' The negative appreciation of reaction proves that regarding the execution of death punishment is somehow wrong whatever its rationals.

\section{b. Appreciation system of composition}

Within this system, composition deals with the way we view the relationship of proportion between the different parts that compose an entity. It is related to perception or our view of order. There is only one appreciation component of composition appears in the editorial. It is used to assess the death execution policy in Indonesia comparing to policy of other countries. It is no better no worse comparing to China and US. So, from the statement in the editorial, Australia knows well that instead of Indonesia that commits on death penalty, there are other countries doing so although for different defendants. In China, death penalty is mentioned for a killing political prisoner and in US, it is called killing murderers. From the editorial, it is understood that any capital punishment has no place in any modern, civilised, and democratic nations. The negative composition assessment shows that it is not fair enough to judge Indonesia in this way as other countries commits so in killing any defendants.

\section{c. Appreciation system of valuation}

Valuation is used for evaluating their social significance in relation to culturally or ideologically established conventions. Editorial of SMH only cites Joko Widodo appreciation to Indonesia. As Joko Widodo is the president of Indonesia, he provides positive appreciation of valuation on Indonesia. He is tough in rejecting clemency for the two Australians and commits to execute both of them in front of firing squad because he already promised in his inauguration that the presence of Indonesia has to be dignified, honourable, and self-esteem becoming a great nation. The invoked assessment means that although Australia complaining on the execution, as the political expendiency of the president, Joko Widodo prefers to execute the drug criminals than submitts to Australia and will perceived as a dictated-country without any authority.

\section{Text 2. HS editorial: Death stalks the Bali Two}

\section{Affect Analysis}

The judgement affect in the HS editorial is for President Joko Widodo from Australian Prime Minister, Tony Abbott. He is judged to be a deafear person.

(13) They are changed men, genuinely so, says Prime Minister Abbott, whose personal appeals to President Widodo appear to have fallen on deaf ears. (HS)

This assessment goes to Joko Widodo with regard to the rejection of the clemency for the two Australian defendants, Andrew Chan and Myuran Sukumaran. Both the men was sentenced in February 2006. For almost decade, they are sent to jail and Prime Minister said nowadays, they are changed men and worth to get clemency from the president.

\section{Judgement Analysis}

\section{a. The judgement system of capacity}

As it is stated that judgement of capacity deals with the personal judgment on how capable the person we judge. The editorial provides negative assesment to Indonesian government, president Joko widodo, and two Australian, Chan and Sukumaran. Rule of power, ignores, weakness are words used to evaluate Indonesia and the word stupid is used to evaluate Chan and Sukumaran.

(14) It shows the Indonesian Government as exercising the rule of power rather than the rule of law. (HS)

From the statement, it said indirectly the policy Joko Widodo taken is actually not following the law but power. Joko widodo has no good capacity on how to rule the nation. As he is the president, it seems he can do anything he likes by ignoring the law. 
Ruling the nation based on the power not the law, it shows the weakness not the strengh of the president.

(15) Many Indonesia politicians and members of the judiciary are against the death penalty and a moratorium on state killing would allow a national debate. That would show strength, not weakness, because weakness is what President Widodo shows now.'

So, instead of a deaf-ear person, Joko Widodo also does not pay attention on the debate of death penalty and killing others in Indonesia. It can be concluded that Joko Widodo is not capable to face and solve any problems in Indonesia.

HS editorial also assesses two Australians who got death sentence because of drug trafficking in negative judgement to be stupid men. It is invoked that what they did in 2005 is stupidity of people. They do not understand the risk of trafficking drugs in Indonesia and the rule for such arrested person for it.

\section{b. The judgement system of tenacity}

Only one judgement of tenacity in HS editorial. It is for President Joko Widodo. 'President Joko Widodo...remains determined to carry out the executions.' Joko Widodo does not lay his shoulder to other country, but as the president of the sovereign country, he stands strong to do what he believes is good for the nation. From the perspective of Australian, it is kind of negative thing as he does not realize the clemency for people who have changed.

\section{c. The judgement system of normality}

Judgement of normality deals with how special of the thing or people. In the editorial, this evaluation is for the execution of death penalty for the Australian.

(16) Preparations for what seems the inevitable execution by firing squad of Chan and Sukumaran ignores an appeal on their behalf still to be dealt with by the Indonesian courts'. (HS)

From Australian perspective, this kind of specialty is negative because it refers to the killing. Something that cannot be avoided means that it is special or extraordinary.

\section{d. The judgement system of propriety}

Judgement system of propriety delivers for the process of transfer for execution and its execution, Chan and Sukumaran, Indonesian government, and president Joko Widodo. Tragic rush, greedy, selfish, cruel and unusual punishement, barbarity, barbarous state, and power crude. All judgements are in negative perspective.

(17) Two greedy, stupid and selfish Australians have turned their lives around in an Indonesian prison. (HS)

(18) What is happening to Chan and Sukumaran is cruel and unusual punishment, with the final barbarity to come from their deaths by firing squad.(HS)

(19) President Widodo's actions have presented Indonesia to the world as a barbarous state, the display of its power crude and unforgiving.

The process of transfering the defendants is categorised into negative thing as a tragic rush and the exucution is a kind of barbarity. Killing other with any reasons is inhuman. Those are assessment for Indonesia. Further, Indonesia is regarded as a barbarous state and the punishement is very cruel and unusual. While Joko Widodo is also judged as a power crude. He only lays on power instead of law.

Then, negative assessment is also for Chan and Sukumaran. They are considered to be greedy and selfish because they let themselves to turn their lives in Indonesia prison. The consequences of greedy and selfish things they did for drug trafficking.

\section{Appreciation Analysis}

\section{a. The appreciation system of reaction}

Analysis of reaction is for Chan and Sukumaran. They are different men as they have been rehabilitated. Although they was sentenced in court and must live in jail for several times, almost a decade, they simply transform to be better persons. They are appreciated in positive way.

For the president Joko Widodo, negative appreciation is assigned. The expression of deaf ears represents Joko Widodo as the person who 
are not able to listen to others. This assessment is simultaneously for appreciation and dissatisfaction. Negative appreciation and negative affect both are for Joko Widodo.

\section{b. The appreciation system of valuation}

In HS editorial, there two kind of valuations, either negative or positive. The negative valuation such as unforgiving and positive valuation such as has been ordained a practising pastor and has been a mentor, and changed man.

(20) ...Chan has been ordained a practising pastor and Sukumaran has been a mentor to other prisoners... (HS)

(21) They are changed men, genuinely so, says Prime Minister Abbott...(HS)

The positive valuations points to Andrew Chan and Myuran Sukumaran, while negative valuation is both for them and president Joko Widodo. The word unforgiving is an expression for the act of executing Chan and Sukumaran. Editor says that it is not kind for expossing powerfulness of Joko Widodo but display the Indonesia as the barbarous country to the world. That is unforgiving.

\section{Ideology Analysis}

Ideological working of language used in the editorials can be noticed from the affect, judgement, and appreciation, either positive or negative. Van Dijk (2000) defines ideologies as a complex nature that may be expressed explicitly and then are easy to detect, but this may also happen very indirectly or implicitly. The overall strategy of most ideological work is (Van Dijk, 2000) say positive things about Us and say negative things about Them. Then, it is generally organized by a general strategy of positive self-presentation (boasting) and negative other-presentation (derogation) (Freeden, 2013; Van Dijk, 2006). It generally operates that our good things are emphasized and our bad things deemphasized, and the opposite for the others whose bad things will be enhanced, and whose good things will be hidden or forgotten.

Here, in the two editorials, the journalists want to expose that Indonesian government and president Joko Widodo individually are bad and wrong while Australia is good and right. The table below indicates the ideological working of language in SMH and $\mathrm{HS}$ editorials.

Table 1.

Ideological Working of Language in Editorials

\begin{tabular}{|c|c|c|c|c|c|}
\hline \multirow{2}{*}{\multicolumn{2}{|c|}{ Attitudinal System }} & \multicolumn{2}{|c|}{ Sydney Morning Herald } & \multicolumn{2}{|c|}{ Herald Sun } \\
\hline & & Indonesia & Australia & Indonesia & Australia \\
\hline \multirow[t]{2}{*}{ Affect } & Positive & - & & - & \\
\hline & Negative & - & $\begin{array}{l}\text { worst fears, } \\
\text { replete with } \\
\text { doubt, }\end{array}$ & - & guilt \\
\hline \multirow[t]{2}{*}{ Judgement } & Positive & - & Right & - & - \\
\hline & Negative & $\begin{array}{l}\text { incapable, evil, } \\
\text { barbarism, gross error } \\
\text { of judgement, cruel, } \\
\text { inhumane, haphazard, } \\
\text { inconsistent, fraud, } \\
\text { culpability, simply } \\
\text { wrong, futility, } \\
\text { inhumanity }\end{array}$ & - & $\begin{array}{l}\text { tragic rush, rule of } \\
\text { power, inevitable, } \\
\text { ignores, determined, } \\
\text { weakness, cruel, final } \\
\text { barbarity, barbareous } \\
\text { state, power crude }\end{array}$ & $\begin{array}{l}\text { greedy, stupid, } \\
\text { selfish }\end{array}$ \\
\hline \multirow[t]{2}{*}{ Appreciation } & Positive & - & - & - & $\begin{array}{l}\text { different men, } \\
\text { changed men, has } \\
\text { been ordained a } \\
\text { practising pastor } \\
\text { and has been a } \\
\text { mentor }\end{array}$ \\
\hline & Negative & have failed & - & deaf ears, unforgiving & - \\
\hline
\end{tabular}


The assessment of Indonesia is dominantly expressed through negative judgement both in SMH or HS editorials. Negative judgement toward Indonesia indicates the editorials are creating a common evil enemy to unite everyone in opposition. Meanwhile, Australia in general is appraised in positive way in SMH editorial, but HS appraises Chan and Sukumaran personally in negative judgement as greedy, stupid and selfish. Negative affect represents the Australian feeling in such condition facing death execution to Chan and Sukumaran in Indonesia.

\section{CONCLUSION}

The editorials are highly evaluative as the editor describes intense feelings and strong reactions to people and things. Editor of both newspaper depict Indonesia in such a way of negative because Australia fights on the capital punishment. Then, through the editorials, editor is trying to unite all Australians agree and support the Australia policy on death penalty. What have been done by Indonesian government or President Joko Widodo is absolutely wrong and need to be protested.

The linguistic strategies used in representing the media ideology are through the use of attitudinal system of affect, judgement, and appreciation. Indonesia is represented in negative judgement and appreciation, while Australia is represented in positive judgement and appreciation. So, one of the ways to uncover the ideology of the media can be from the linguistic strategies used, in particular, from appraisal perspective.

\section{REFERENCES}

Bloor, Thomas and Meriel Bloor. (2004). The Functional Analysis of English. A Hallidayan Approach. Second Edition. London: Arnold

Clark, Urszula. (2007). Studying Language. New York: Palgrave Macmillan.

Coffin, C. (2001). Theoretical Approaches to Written Language - a TESOLperspective. In Burns, A \& Coffin, C (eds.). Analysing English in Global Context. Pp. 93-122. Routledge

Entman, R. M. (2007). Framing bias: media in the distribution of power. Journal of Communication, 57(1), 163-173.

Fairclough, N. (2003). Analysing discourse: textual analysis for social research. London: Longman Group Limited.

Fowler, R. (1986). Linguistic Criticism. Oxford: Oxford University Press

Freeden, Michael. (2013). The Meaning of Ideology: Cross-Disciplinary Perspectives. London: Routledge

Gay, L.R., Mills, G.E. \& Airasian, P. (2006). Educational Research. 8th edition. New Jersey: Pearson Education.

Halliday, M. A. K. (1971). Linguistic Function and Literary Style: An Inquiry into the Language of William Golding's the Inheritors. In Chatman, S. (Ed.), Literary Style: A Symposium (pp. 330-368). New York: Oxford University Press.

Halliday, M.A.K. and Christian Matthissen. (2004). An Introduction To Functional Grammar. Third Edition. London: Hodder Arnold

Halliday, M.A.K. and Ruqaiya Hasan.(1989). Language, Context, and Text: Aspects of Language in a Social-Semiotic Perspective. Oxford: Oxford University Press

Haratyan, Farzaneh. (2011). Halliday's SFL and Social Meaning. 2nd International Conference on Humanities, Historical and Social Sciences. IPEDR vol.17, 2011. Singapore: IACSIT Press.

Imhonopi, D. \& Urim, C. (2004) Current issues in Sociology of Mass Communication. Dugbe: Euphrates Publishers.

Martin, J. R. and P. R. R. White. (2005). The Language of Evaluation. Appraisal in English. New York: Palgrave Macmillan

Medubi, O. (2007). The Fundamentals of Journalism. In Olu Obafemi, G.A. Ajadi, V.A Ababi (eds.) Critical perspectives on English language \& literature. Ilorin: The Dept. of English. (p 105 and 116)

Storall, J. (2005). Journalism: who, what, when, where, why and how. Boston: Education Inc.

Van Dijk, T.A. (1996). Opinions and Ideologies in Editorials. Paper for the fourth international symposium of critical discourse analysis, language, social life and critical thought, Athens: 14 - 16 December 1995. Accessed March 15, 2015 http://www.hum.uva.nl/ teun/A/ideology2.htm

Van Dijk, Teun A. (2000). Ideology and Discourse. A Multidisciplinary Introduction. Open University.

Van Dijk, Teun A. (2006). Ideology and discourse analysis in Journal of Political Ideologies, No. 11(2) page 115-140, June 2006. Routledge 